This is the accepted version of a forthcoming article that will be published in Feminist Review by Palgrave Macmillan: http://www.palgrave.com/gb/journal/41305

Accepted version downloaded from SOAS Research Online: http://eprints.soas.ac.uk/25115/

Accepted 24-11-2017

Navtej Purewal (2018) 'Sex Selective Abortion, Neoliberal Patriarchy and Structural Violence in India,' Feminist Review, Issue 119, July. 
This is the accepted version of a forthcoming article that will be published in Feminist Review by Palgrave Macmillan: http://www.palgrave.com/gb/journal/41305

Accepted version downloaded from SOAS Research Online: http://eprints.soas.ac.uk/25115/

\title{
Sex Selective Abortion, Neoliberal Patriarchy and Structural Violence in India
}

\begin{abstract}
This article explores sex selective abortion (SSA) as a form of structural violence within the broader notion of women's 'protection' in contemporary India. While SSA tends to be framed more generally within ethical and choice-based frameworks around abortion access and reproductive 'rights' and specifically in India around preference for sons as a discriminatory, cultural, technological misogyny, this article argues that sex selective abortion in India needs to be understood as an outcome of broader systemic economic, political and social processes. The deepening of neoliberal values, economic processes, and state policies has impacted significantly on social relations which shape SSA as a manifestation of structural violence. State-driven policies in India reflect a neoliberal governmentality through state patriarchy which are implicit within the neoliberal developmental, governmental and capitalist paradigm of contemporary India. This article argues that SSA is structurally produced and therefore cannot be remedied through awareness-raising strategies such as 'beti bachao' or financial inclusion as a means to 'protect' or 'save the girl child'. Indeed, it is neoliberal economic forces which actively, though seemingly inadvertently, promote anti-women, sex selective abortion as a reproductive strategy which is then disciplined through neoliberal governmentality. This highlights SSA as a form of gendered and structural, rather than discriminatory, violence.
\end{abstract}


This is the accepted version of a forthcoming article that will be published in Feminist Review by Palgrave Macmillan: http://www.palgrave.com/gb/journal/41305

Accepted version downloaded from SOAS Research Online: http://eprints.soas.ac.uk/25115/

\section{Introduction}

Immediately after the election of the Bharatiya Janata Party (BJP) government in May 2014, there was an acceleration of both an aggressively market-oriented neoliberal economic agenda emphasising an open and 'modern' capitalist economic model and a conservative social agenda emphasising 'traditional' values through a combined patriarchal and Hindutva ideology. This paradigm was crafted through a converged promotion of Hindutva and neoliberalism, with women projected as receivers of gifts and 'protection', rather than having 'rights' or entitlements. This was the focus of the Pradhan Mantri Jan Dhan Yojana (PMJDY) ${ }^{1}$ scheme launched in August 2014. PMJDY was announced in time for the occasion of Raksha Bandhan (translated literally as 'bond of protection'), when sisters (real or figurative) tie a thread on the wrist of their brothers (real or figurative) and in return receive gifts or money as a symbolic ritual about the 'protection' that is promised to the sisters by the brothers.

Figure 1. Ornamental raakhi with Prime Minister Modi’s photo

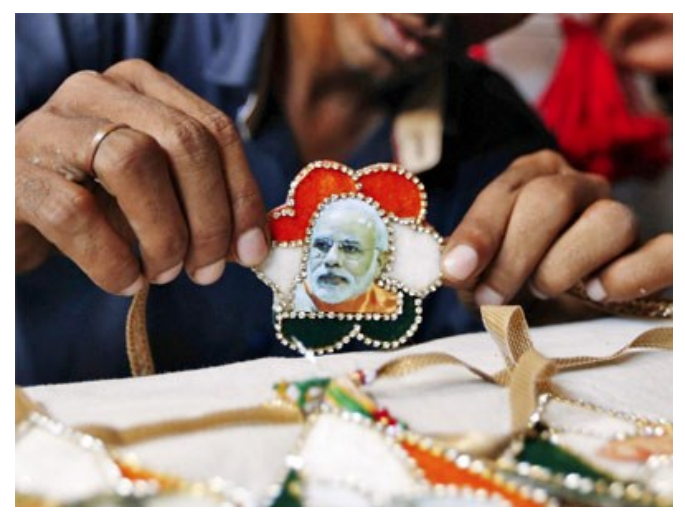

Source: Economic Times (2015)

This highly patriarchal ritual was capitalised upon by the newly elected Modi government which rolled out a mass banking account scheme in the name of 'protection' for sisters. This was a symbolic insertion of normative patriarchal ideology and social relations into the capitalist, neoliberal financial inclusion of women through patrimony into the 'bond of protection', an apt example of neoliberal patriarchy. From there onwards, women's 'protection' and 'safety' has become a visible feature of the post-2014 Indian

\footnotetext{
${ }^{1}$ The Jan Dhan Yojana scheme falls under the Department of Financial Services, Ministry of Finance in
} the Indian government. https://pmjdy.gov.in/ 
This is the accepted version of a forthcoming article that will be published in Feminist Review by Palgrave Macmillan: http://www.palgrave.com/gb/journal/41305

Accepted version downloaded from SOAS Research Online: http://eprints.soas.ac.uk/25115/

government's rhetoric of an emerging patriarchal, neoliberal state with Narendra Modi as the symbolic patriarch of Hindu nationalist India. As part of a larger campaign called Beti Bachao, Beti Parhao andolan (transl. 'Save the daughter, Educate the daughter'), a distinctive victim discourse hinged on upliftment of daughters has continued. The social contract, previously based on normative notions of 'traditional' patriarchal culture, practices and social relations, has now explicitly been linked to social and economic policies promoting upliftment and 'protection,' deepening ties of male proprietary rights over women, and neoliberal financial processes.

The triad supremacy of patriarchy, neoliberalism, and Hindutva was firmly established not only in terms of rhetoric but also through policy. Women's 'protection' and 'safety' became a cornerstone of the BJP government's social agenda which operates in tandem with the neoliberal economic agenda. This article aims to draw attention to the ways in which developments around sex selective abortion (SSA) in particular, highlight the structural dimensions of the biopolitics of SSA that shape state policy and discourse. The BJP Modi government, in this respect, is a neoliberal state patriarchy, which has actively promoted the strategic use of gender insecurity and violence for exercise of its political power at all levels of society from the state to the community, household, and interpersonal levels. The hyping of alarmist discourses and moral panics on gender 'insecurity' (notably after the 2012 rape and murder or Jyoti Singh Pandey in Delhi) reflects a close link between the rise to ascent of neoliberalism as an ideological project ('free market' and 'individual responsibility') and a set of governmental practices (punitive and proactive law enforcement) targeting 'the margins and cracks of the new economic and moral order coming into being under the conjoint empire of financialised capital and flexible wage labour' (Wacquant 2009:1). The 2014 election of the BJP government marked a new era of neoliberal governance and governmentality through the invocation of Hindutva ideology as a further legitimating dimension.

To understand the structural levels of SSA as gender violence, it is important to recognise the apparatus of the exercise of political, social and economic control and power. Neoliberalism and Hindutva provide the ideological means by which to shape and utilize patriarchy at all levels. In a context of a state which poses the 'threat' of minorities to a Hindu majority nation and constructs 'safety' of women as being under threat, 'structural 
This is the accepted version of a forthcoming article that will be published in Feminist Review by Palgrave Macmillan: http://www.palgrave.com/gb/journal/41305

Accepted version downloaded from SOAS Research Online: http://eprints.soas.ac.uk/25115/

violence may be seen as natural as the air around us' in maintaining social order (Galtung 1969: 173). For our purposes here, therefore, to view SSA as a form of structural violence is in direct opposition to analyses and policies which either focus on the 'rights' discourse or the anti-discrimination logic which seeks to uplift or 'save' girls and women through various schemes and programmes. The outcomes of social and public policies towards 'saving the girl child,' for instance, highlight how the rights and anti-discrimination discourses are a part of the structures which produce skewed sex ratios and the broader processes of economic, political, social, emotional and other violences. The awarenessraising and incentive schemes further show how a charitable disposition towards daughters and 'the girl child' are actively promoted within such schemes, which reinforce women's dispossession and, rather than challenging the perception of daughters as burdens or victims, neoliberal patriarchy is deepening and further entrenching it.

\section{Neoliberal patriarchy and governmentality in India}

The era of neoliberal governmentality, marked by an increasingly entrenched international and supranational development agency discourse across the 'global South', exhibits the move towards promoting empowerment strategies while instructing developmentalist states such as India to promote market interventions and to cut welfare provisions. Developmentalist states and development projects have widely employed the concept of empowerment since the mid-1990s. Even while particular projects may not be neoliberal in their design or premise, the use of empowerment strategies has been conveniently utilised as a means by which to show small-scale, participatory governance and market-based principles. This has been done while there has been a dismantling of direct provision of basic needs for the marginalized/disadvantaged in order for them to supposedly be able to better govern and sustain their own development needs (Gupta 2006). As Gupta and Sharma argue:

the fact that the very institutions whose structural adjustment policies have had intensely disempowering (my emphasis) effects on marginalised people across the global are encouraging and funding grassroots empowerment through the lens of neoliberal governmentality (2006: 284). 
This is the accepted version of a forthcoming article that will be published in Feminist Review by Palgrave Macmillan: http://www.palgrave.com/gb/journal/41305

Accepted version downloaded from SOAS Research Online: http://eprints.soas.ac.uk/25115/

While the state has been culturally constructed as being outside of the domain of society through its authoritative and arguably masculinist character, the neoliberal state's boundaries exist from within society which highlights how it is deeply embedded and embodied in the very structures of power its policies are set up to address (Sharma 2010). Harris-White (2010) has highlighted how 'de-regulation' and liberalisation since the early 1990s led to the restructuring, reduction, and even removal of welfare provisions. As a result, existing state welfare activities began to be either turned into 'entitlement programmes' or managed and delivered by NGOs tied to global supra-international institutions. The UN Conference on Population and Development (ICPD) in Cairo in 1994 paved the way for the NGO-isation of reproductive health policy and services, with India's sex ratio and the crisis of the 'girl child' as the cornerstone (Rao 2004). Cairo 1994 solidified alliances between liberal feminists who were committed to reproductive (individual) 'rights' and the neo-Malthusian population control advocates. The outcome of this was the establishment of a 'rights' and 'empowerment' discourse on women's reproduction which simultaneously saw a shift from an emphasis on government-run services towards the 'NGOisation' of reproductive health service delivery. As a result, the Indian state came under pressure to engage with the international NGO community in 1994 about its reproductive health policies, including its approach to address its sex ratio problem. State campaigns to address the victimhood of the 'girl child' from 1994 onwards in India were accompanied by monitoring and analysis of demographic data (Purewal 2014). The UNFPA and other national and international agencies facilitated the tracking of sex ratios and drew the causal relationship between reproductive technologies and declining sex ratios against females. New systems of surveillance of reproductive histories and patterns were employed during the mid-2000s when there was an expansion of internet and digital technologies within bureaucracies. Digital databases and the tracking of birth and pregnancy records began to be employed in joining up disparate information across departments in order to show accountability and attentiveness to sex selection as a matter of reproductive governance and governmentality. This approach was hinged on a 'tradition' meets 'modernity' approach and a view that skewed sex ratios signified a convergence between gender discrimination/violence and reproductive technologies. In adopting Grint and Woolgar's (1995) concept of gender and technology as being mutually shaping and co-constructing, SSA highlights how gender violence and technology are intrinsic to and mutually constitutive of one another. 
This is the accepted version of a forthcoming article that will be published in Feminist Review by Palgrave Macmillan: http://www.palgrave.com/gb/journal/41305

Accepted version downloaded from SOAS Research Online: http://eprints.soas.ac.uk/25115/

The liberalisation of the Indian economy after 1991 meant that the state became increasingly malleable for executing the neoliberal paradigm through social and economic policy. Even prior to 1991, however, the Indian state was not hostile to capitalist interests within the social and health sectors. The rise of corporate hospitals during the 1980s saw the proliferation of medical (including reproductive) technologies, increased access to drugs, equipment and other medical materials which were more readily obtained through loans from financial institutions and banks (Srinivasan 2004). In 1998 it was estimated that eighty percent of health care expenditure by individuals in India was on private services and the range of services showed that from 'the corner x-ray clinic to the drug-company-funded corporate hospital...(private services were) more accessible than government services' (Ibid, p. 57). After 1991 when global capital entered a new era in India's economy, these patterns intensified with the small-scale private health care industry as well as the large-scale corporate health care industry expanding at rates exponential to that of public health care. However, rather than being absent from these shifts, the Indian state was a key agent in creating favourable conditions for capitalist interests (Harris-White 2010a: 170).

The deepening of neoliberalism since 1991, alongside the social sector's explicit evocation of patriarchy as a form of social organisation and a set of values to be promoted through discourse and policies, has shaped India's neoliberal governmentality. Patriarchy and the domestic mode of production, rather than being pre-capitalist or 'backward' forms of social relations existing in distinction from capitalist development, are inherently tied to the international and global dimensions of capitalist expansion and penetration. However, the form of social organisation and exploitation of labour does not necessarily translate into a roadmap of relations of production (Banaji 2010), and the sustenance of patriarchy as a resilient ideology is an example of how capitalism has utilised and exploited 'pre-capitalist' relations of production in furthering its aims of expansion and penetration.

A more conventional definition of patriarchy is that it represents a system in which men hold power and women are largely excluded from it. This general definition has evolved as it continues to find new collusions with other forms of dominance and hegemony. The 
This is the accepted version of a forthcoming article that will be published in Feminist Review by Palgrave Macmillan: http://www.palgrave.com/gb/journal/41305

Accepted version downloaded from SOAS Research Online: http://eprints.soas.ac.uk/25115/

state, along with the family and community, has been the most significant advocate and purveyor of patriarchy. State patriarchy as a form of governance and an apparatus of governmentality, has projected a hierarchical regime which obliges men and women to fit into a system of social organisation accordingly. As Patricia Owens (2015) poignantly highlights, the scaling up of oikonomia, or household management, to the realms of social policy and governance has marked a recasting of 'the social' in order to respond to, quell and assert dominance over resistances from below. Thus, domestic 'homologies' are constituted by emerging configurations and links between forms of despotic patriarchal household rule and evolving forms of social government. Neoliberal patriarchal governmentality in India casts light on the ways in which 'the rise of the social' can be seen as a core element of how hierarchies of household rule relate to strategies of governance and governmentality. As Wendy Brown (1992: 12) argues, the state is fundamentally fraught: "the paradox that what we call the state is at once an incoherent, multifaceted ensemble of power relations and an apparent vehicle if not agent of massive domination.' State patriarchy is thus inextricably tied to forms of dominance such as male-domination, class and caste, which highlights the state's complicity and position in relation to violences which are produced despite or in relation to laws, institutions, and public life. Thus, making appeals to the state to broker and lever a politics of protection and regulation is a fraught strategy for engagement with the state. As Brown further argues: 'the state is neither hegemonic nor monolithic, but it mediates or deploys almost all the powers shaping women's lives- physical, economic, sexual, reproductive, and political - powers wielded in previous epochs directly by men... male social power and the production of female subjects appears to be increasingly concentrated in the state (Ibid, p. 29).

The neoliberal state's core function, as Wacquant (2009) highlights, is to facilitate the penetration of neoliberalism and private capital. Its aims are thus to reduce welfare, to create a punitive apparatus projecting inequality and social insecurity (necessary ingredients for neoliberal governmentality), as well as to promote the trope of the individual within the minimizing role of the state in admonishing it of its role in representing collective or cooperative responsibility. As the neoliberal state dismantles its welfare provision and investment in public and social services and health care, it also exhibits manifestly repressive features as it hollows out the modern subject through the 
This is the accepted version of a forthcoming article that will be published in Feminist Review by Palgrave Macmillan: http://www.palgrave.com/gb/journal/41305

Accepted version downloaded from SOAS Research Online: http://eprints.soas.ac.uk/25115/

diminishment of democracy in order to carry out this process (Harvey 2005, Brown 2015). The repressive features of the neoliberal Indian state are not only a function of the state's punitive function, but are also driven by existing punitive ideologies and social structures of violence in order to fulfill its role. Patriarchy provides a ready-made ideology upon which to project insecurity as a necessary threat to non-conformity and a basis for the logic of governmentality in order to enact 'protection'. While neoliberalism has produced a market-based ethical framework shaping values, ideas, ideology, and practices (Harvey 2005), its machinations into all aspects of state, economy and society requires further attention to trace how, as Campbell (2015) states: 'sexism constantly finds new cultures and contexts, while violence and sexual aggression continue to attract impunity'. It is the impunities generated by the structures surrounding SSA which neoliberal patriarchy relies upon in order to extract, repress, and delimit any potential threats to its extant authority.

Patriarchy operates at the levels of the nation, the household, and community, representing structures of control (and violence) throughout. Simultaneously, any threats to the sanctity of the patriarchal state, household or community are viewed as matters of 'security' or 'protection' in order for male-centred power to fulfill its duties. Neoliberal patriarchy requires a form of governmentality to enforce 'protection' in order to mete out threats to its security in ensuring the smooth functioning of patriarchal and capitalist social and economic relations. The newly elected Modi government in the summer of 2014 escalated the hyping of gender insecurity through a number of campaigns which both capitalised upon the post-2012 Delhi rape discourse on women's 'safety' and 'protection' meanwhile projecting a communal, anti-Muslim threat to Hindu supremacy. The anti- 'Love Jihad' campaign waged by the Hindu right in 2014, alleged that Muslim men used the lures of romantic relations or 'love' as a ploy to convert Hindu women to Islam. Accordingly, it was claimed that Hindu women must be 'protected' from such a conspiracy which would be a threat to India as a Hindu majority nation. Women's autonomous choices in relation to challenging patriarchal authority were silenced and, as feminist commentators clearly highlighted (Sarkar, this issue), women were made vulnerable to 'honour' violence and moral policing, as a result of the campaign.

The rise of Hindutva in India has not only seen the BJP come to electoral power since 
This is the accepted version of a forthcoming article that will be published in Feminist Review by Palgrave Macmillan: http://www.palgrave.com/gb/journal/41305

Accepted version downloaded from SOAS Research Online: http://eprints.soas.ac.uk/25115/

2014 (and earlier 1998-2004) but also the Sangh Parvar and broader Hindu majoritarian groups have alongside come into formal and informal power at various levels of state and non-state spaces. A key feature of this era has been formal incitement of insecurity along 'communal' lines in generating a polarised and politicised Hindu-Muslim discourse in order to assert the 'Hindu nation' as supposedly being under threat by internal and external Muslim forces (Sarkar 2001). Gender insecurity has been pitched within the communal discourse of Hindutva. For instance, in February 2017 BJP President Amit Shah pledged to voters that if elected in the state of U.P., the BJP would instruct 'antiRomeo'2 squads as defacto moral police in making women safer. The BJP, after winning the U.P. election in March 2017, appointed long-time RSS activist Yogi Adityanath as the new Chief Minister of the state. Adityanath had over the years voiced explicit statements to incite violence against Muslims as well as opposition to women's reservations, having voted against the Women's Reservation Bill in 2010. He had also made public statements including the need for women to be 'protected' rather than accounted for in representational politics: 'Women should always be protected. Energy that's left unchecked can go to waste. A woman doesn't need independence, but needs to be protected and channelised' (Suhasini 2017).

In a similar move to extend state powers through the police in the neighbouring state of Madhya Pradesh, BJP MP Shivraj Singh Chauhan announced soon after his appointment as Chief Minister in March 2017 that 'anti-Majnoo'3 squads would be formed by the police to take stern measures against criminal elements' (Jandial 2017). It was not surprising that immediately after the election result there was explicit anti-Muslim rhetoric coming through official channels alongside the public presence of informal antiRomeo squads. Violence enacted by such forces has seen incidents since 2014 such as lynchings by mobs on the basis of rumours of 'cow killing' and dalits and Muslims being publicly humiliated for socially transgressing caste and communal lines with impunity to

2 The concept of anti-romeo dals (or squads) was more or less introduced in the build-up to the February/March 2017 elections as a BJP electoral promise to 'protect women's honour' by placing checks on 'eve-teasing' and, depending on the seriousness of the case, to give warnings, to inform parents or to initiate criminal proceedings against the accused.

http://www.news18.com/news/india/what-are-anti-romeo-squads-how-do-they-operate-points-toknow-1362855.html

${ }^{3}$ Laila Majnu (Majnoo) is a $10^{\text {th }}$ century epic love story which ends in tragedy after Majnu falls in love with Laila at first sight. The story ends in tragedy when Majnu is killed by Laila's brothers when, in the hope of averting violent confrontation, she disarms Majnu by hiding his arrows followed by him being killed by her brothers. 
This is the accepted version of a forthcoming article that will be published in Feminist Review by Palgrave Macmillan: http://www.palgrave.com/gb/journal/41305

Accepted version downloaded from SOAS Research Online: http://eprints.soas.ac.uk/25115/

the perpetrators, just as had occurred in Gujarat after the 2002 pogroms when Narendra Modi was Chief Minister of the state. Only four years earlier in September 2013 one of India's worst episodes of collective violence against Muslims occurred in Muzaffarnagar U.P. only several months before the national elections were to be held. The state, therefore, cannot be viewed merely as an instrument of governance once electoral power has been gained but needs to also be understood in terms of the processes by which politics is constituted and how structures of violence and security/insecurity are part and parcel of the state apparatus and not outside of it. The Punjab state Akali Dal government, one of the BJP's key coalition partners in the 1998-2004 NDA government, exemplifies the neoliberal patriarchal state in the feudal father-son Prakash Singh and Sukhbir Singh Badal government. Through the launching of a project called Nanhi Chhaan ${ }^{4}$, MP Harsimrat Kaur Badal, the wife and daughter-in-law of then Deputy and Chief Minister, announced the project's aims to save the girl child and the environment through the project supported by the SGPC, the Sikh seat of authority in Amritsar, and global pharmaceutical giant Ranbaxy through its 'corporate social responsibility' agenda, an Indian company which was alleged to have distributed substandard and adulterated drugs in the US. While neoliberal processes within feudal and patriarchal structures in Punjab had dramatically deepened during the Akali Dal's period of rule until March 2017 through the concentration of private ownership of media, transport, and business within their (feudal) networks, the Nanhi Chhaan 'girl child' and environment awareness-raising programme served a performative function of governmentality with religious and corporate sanction in projecting an image of benevolence rather than violence.

The household level also provides a significant dimension to our understanding of structural power and how it relates to gender security. The domestic mode of production which shapes the economic base provided by patriarchy and patrimony (gifts, inheritance, power and hierarchies of status, and entitlements within the family) has been brought into the neoliberal projection of the family as a significant sector of the economy in terms of labour and production. Within the symbolic realm of economic entitlements and norms of transmission of capital through inheritance, sons receive land and/or property within norms of inheritance, while daughters are given gifts or dowries which require them to

\footnotetext{
${ }^{4}$ Nanhi means 'daughter' or 'young girl' and Chhaan literally means 'shade' from the sun but here means protection and refers to the protection of the environment and the 'girl child'.
} 
This is the accepted version of a forthcoming article that will be published in Feminist Review by Palgrave Macmillan: http://www.palgrave.com/gb/journal/41305

Accepted version downloaded from SOAS Research Online: http://eprints.soas.ac.uk/25115/

marry and exist non-autonomously, thus entrenching them within the patriarchal structures of not only their natal family but also their marital family (Delphy 1988). Indeed daughters' entitlements are undermined by their circumscribed position as noninheriting members of the household unit. Viewing this dynamic of daughter's/sister's subjecthood in the family, Veena Das (2000: 212) argues that 'time is a destroyer of relations' as a continual mediator in (patriarchal) family dynamics and that there is a temporal and ephemeral nature to how stakes may be claimed by a woman on her natal home.

Neoliberal patriarchy not only draws upon women's non-autonomous subjecthood in capitulating to the authority and structures of 'tradition' and the temporal nature of claims but also reshapes them in order to extract paid and unpaid labour in regulating women's mobility, activity and positionality within social and economic structures. The inherently contradictory and hegemonic nature of neoliberalism in India has seen the 'pulling' of women out into the market as workers, producers, development project targets, and consumers, meanwhile, there has been a 'pushing back' of women through the discourse of 'safety' through moral policing, patrimony and patriarchal gender 'norms' as noninheriting, domesticated, and territorialised bodies. Perhaps a more fundamental contradiction has emerged through the enhanced notion of individual 'rights' and demands for gender justice in India. Female bodies either need to be protected from 'other' competing patriarchal authorities (such as sexual harassment outside of the home) or destroyed by one's own family through sex selection in order to maintain the sense of 'peace' by upholding and maintaining patriarchal masculinity/misogyny through the birth of sons as a strategy for 'security.' It is at this juncture between the 'pulling out' of women through capitalist and neoliberal processes and the 'pulling back' of women through the discourse of 'tradition' where sex selection, pregnancy and the politics of reproduction presents a nodal point between 'violence' and 'peace' within hegemonic gendered, patriarchal structures and neoliberal values. Sangari (2015) highlights how sex selection operates as a means towards insecuritisation which the family both projects and absorbs:

the family is thus poised on a major contradiction with the neoliberal turn... (it) must perform (in class-differentiated ways) two opposing, even incommensurable, functions at once. It must produce 
This is the accepted version of a forthcoming article that will be published in Feminist Review by Palgrave Macmillan: http://www.palgrave.com/gb/journal/41305

Accepted version downloaded from SOAS Research Online: http://eprints.soas.ac.uk/25115/

daughters as insecure gendered subjects who can settle for little, have a weak sense of their entitlements and inalienable rights (the practice of sex selection does accomplish this), can adapt to the denial of rights, as well as be waged workers, microcredit-sensitive debate repayers, consumers - that is, fit into both ends of the economy.

SSA exists at the outer limits of state, family and individual articulations of and engagements with patriarchy. SSA, thus, is both a form of violence (exploitation, conflict, oppression) and peace (the absence of violence, harmony). If patriarchal authority is a fundamental part of the foundations of how the neoliberal turn has been adopted and absorbed in India, then it is infused with the idea that peace and violence are not on opposite ends of a spectrum but are in fact tied to the structures that uphold the system itself. In rejecting a narrow definition of violence, Galtung (1969:168) posits that 'too little is rejected when peace is held up as an ideal...highly unacceptable social orders would still be compatible with peace.' Building on the idea that patriarchy, neoliberalism and Hindu supremacism are all structurally constituted by violences, their embodiment in the neoliberal state in India raises questions around what policies aiming to address 'discrimination' represent. Neoliberal patriarchy in contemporary India at all levels across the family to the state simultaneously projects a discourse of 'tradition' and 'safety' (an extension of 'peace,' for our purposes here) meanwhile providing an apparatus for structural control and structural violence which creates a repressively contradictory yet affirmative 'protection' of women and their interests.

\section{The state of sex selective abortion in India}

Sex selection has been woven into population policy in India through its Malthusianinspired approach towards population control. Discourses and policies towards 'overpopulation' on the one hand and skewed sex ratios on the other have meant that the methods of coercive reproductive policies to control population have been simultaneously mirrored by punitive (at least in rhetoric) policies to ban sex selective abortion. From the mid-1990s, alongside pursuing a Malthusian approach towards population control, the Indian government embarked on stigmatising female 'de-selection' by employing the label kurimaru (transl. daughter-killing) to states showing a low sex ratio in its official 
This is the accepted version of a forthcoming article that will be published in Feminist Review by Palgrave Macmillan: http://www.palgrave.com/gb/journal/41305

Accepted version downloaded from SOAS Research Online: http://eprints.soas.ac.uk/25115/

discourse on SSA in order to encourage states to achieve set targets to improve their respective ratios (Eklund and Purewal 2017).

The emergence of the sex ratio as a tool for the state to exert its influence over populations in India is not recent. British colonial administrators, intent on developing a strategy for dominance and hegemony in South Asia in the Nineteenth Century identified, documented, and eventually codified 'missing women' and female infanticide in various reports, District Gazeteers, and the Census of India through the sex ratio (Major 2005; Sen 2002; Panigrahi 1972; Vishwanath 2000). This ratio of males to females became a key indicator for the colonial and then postcolonial Indian state for understanding reproduction for governmentality and economic extraction, rather than any concrete or abstract notion of 'rights,' development, or gender equity. While the 'civilising mission' provided the backdrop for a state-level discourse on sex selection in the discovery and identification of infanticide as a form of violence against women, the colonial state was clearly not interested in altering gender relations insofar as this would mean destabilising imperial objectives for penetration of capital into India. Similarly, if society. was tampered with in altering the structural dimensions of a society which was being shaped for capitalist, imperialist economic and political control, this would have detracted from the objectives of utilising existing systems of social organization for political and economic expediency (Oldenburg 2002).

The civilising mission's primary legacy in relation to sex selection in India is that induced abortion was made illegal by the Indian Penal Code in 1860, which identified sex selection as a cultural practice while denying women in India reproductive autonomy by criminalising abortion. It was not until 1971 that abortion was made legal when lobbyists from within the medical profession and women's movement mobilised for a national campaign against unsafe abortion. This led to the legalisation of abortion in the Medical Termination of Pregnancy Act (MTP) of 1971 (Visaria et al 2007). While the MTP Act of 1971 legalised abortion up to and not after 20 weeks of gestation, there was an amendment proposed in October 2014 to extend this to 24 weeks, which is still pending ratification. Nonetheless, population control, rather than improving reproductive health and access to services, has continued to shape the Indian state's population policies since then. This is despite India being cited as the first country to introduce state-led family 
This is the accepted version of a forthcoming article that will be published in Feminist Review by Palgrave Macmillan: http://www.palgrave.com/gb/journal/41305

Accepted version downloaded from SOAS Research Online: http://eprints.soas.ac.uk/25115/

planning programmes in 1952 and the first country in the 'global South' to legalise abortion in 1971 (Visaria 2007).

India was a significant example for the international context of population policy discourse throughout the 1950s, 60s and 70s. India was held up as an example by the international community for its 'population problem' in relation to poverty and development assistance, namely by USAID, the Asian Development Bank and the World Bank. The paranoia generated as a threat to security to the global North and global South elites by demographic patterns of 'explosion' and 'expansion' made the female reproductive body, most notably in India, the focus of demographic fears and policies. Achieving population control targets was made a condition for development aid. The Malthusian prism through which economic 'development' was viewed made a direct correlation between over-population and poverty. As a result, the Indian Planning Commission adopted sterilization as its campaign to tackle population growth. While the available indicators show a decline in the population growth rate with the average number of children per woman falling between 1972 and 2008 from 5.2 to 2.6 (Registrar General of India 2008), this was also a time period during when coercive techniques such as mass sterilisations and unsafe contraceptive implants and injectable drugs (Wilson, this issue) were embedded within population policy and programmes. Private capital has also been a partner in many of these programmes in terms of the incentives offered, including rewards of tubewells and household appliances in return for undergoing sterilisations (Kasun 1999) as well as through drugs trials, vaccine programmes and distribution of unregulated drugs carried out by local 'service providers', such as what occurred in Chhatisgarh in 2013 (Ibid). The neoliberal state's protection of Indian and global capital has meant that controls and regulations have been foregone for the distribution of drugs in the name of population control and 'development.' Though no direct link has been made between Ranbaxy, the Indian pharma corporate giant who is one of the largest global producers and distributors of anti-biotics, and the Chhatisgarh tragedy, it is noteworthy that the same company which had led on the Nanhi Chhaan project in 2008 in Punjab as an act of 'corporate social responsibility' has since been served with a ban on imports of its anti-biotics to the EU and the U.S. due to inspections which showed lack of regulatory procedures and a failure to comply with rules on the sterilization of equipment at the manufacturing plant. 
This is the accepted version of a forthcoming article that will be published in Feminist Review by Palgrave Macmillan: http://www.palgrave.com/gb/journal/41305

Accepted version downloaded from SOAS Research Online: http://eprints.soas.ac.uk/25115/

While testing and the distribution of unregulated drugs occurs in some areas, in others there are no available contraceptive and reproductive health services. For example, in the northeast area of Nagaland, the lack of available reproductive health services has meant that many women are forced to abort as a means of birth control, while the promotion of local unregistered and unqualified 'quacks' and pharmacies has resulted in numerous casualties (Chinai 2004). From the onset, population policies have been target-driven and shaped by coercive and incentivised strategies, with a focus on population control. India's population campaigns have subsequently turned towards women in terms of birth control and tubal ligation. While the right to safe abortion services has been the main concern of the broader feminist movement beyond India regarding reproductive health, son preference and SSA pose further questions around women's control over their bodies versus coercive control and 'choice' in India (whether daughter de-selection is a form of violence or an act of 'choice' or even 'security'). The family is simultaneously a site of 'security' and a site of violence and, as such, structural violence requires examination for its role in situating women within economic and social structures which seemingly protect them while also exerting different forms of violence on them. While 'good daughters' in the family are those who make no demands on parents for inheritance (i.e. economic violence), despite women's legal rights to inherit in India (i.e. political violence), they also understand the threat of being ostracised from their families or stigmatized as 'selfish sisters' (i.e. psychological and emotional violence) within the rules of patriarchal ideology (Kelkar 1992: 118). 'Good daughters' at the state level of patriarchy are therefore those who make no demands on the state for 'rights' or entitlements but who are also workers to be offered up for neoliberal production or potential births to be eliminated. This highlights how the neoliberal state requires the compliance and malleability of the family unit and, as such, mirrors the structures and symbolisms of the patriarchal family unit in its expressions of state patriarchy at all levels.

With the advent of reproductive technologies to aid in the identification of the sex of the fetus since the early 1970s through amniocentesis and soon thereafter with the ultrasound scan and sperm sorting, much has been said about how pre-natal diagnostic and preselective technologies are shaping gender and reproductive politics (Patel 1989; Ravindra 
This is the accepted version of a forthcoming article that will be published in Feminist Review by Palgrave Macmillan: http://www.palgrave.com/gb/journal/41305

Accepted version downloaded from SOAS Research Online: http://eprints.soas.ac.uk/25115/

1995; Retherford and Roy 2003; Rowland 1992; Corea et al 1985; Strathern 1992; Menon 1995; Patel 2007). The mobilisations during the early 1990s by medical, social and feminist activists to legislate against SSA saw the Pre-Natal Diagnostic Test Act 1994 and its follow-up PCPNDT in 2003 which also included pre-conception technologies making the disclosure of the sex of the fetus a punishable act by law. However, despite this legislation being enacted, sex ratios across India continued to decline against females while virtually no cases emerged or resulted in any form of legal action. The social outcomes of demographic gender 'imbalance' have been extensively considered in terms of marriage trends, fertility patterns, family-building strategies, inter-generational transfer of resources, and other societal dynamics seen as consequences of son preference and SSA (Kaur 2013, John et al 2009; Chowdhry 2011). While the sociology of son preference and sex selection is replete within the literature on the sex ratio, the state's implicit role in the production of structural violence has been less explored (Sangari 2015).

Figure 2 shows the 'bobbing effect' of the trends of the total population revealing that the sex ratio from 1961 (941) compared to 2011 (940) only went down one point. However, the sex ratio of the 0-6 child population shows a steady decline from 1961 (976) to 2011 (914) with a notably steep downward trend after the introduction and increased accessibility of the ultrasound scan and other sex selective technologies between 1981 to 2011, showing decadal movement of -17 from 1981-1991, -18 from 1991-2001; and -13 between 2001 and 2011.

Figure 2. Overall Sex Ratio and Child Sex ratio in India

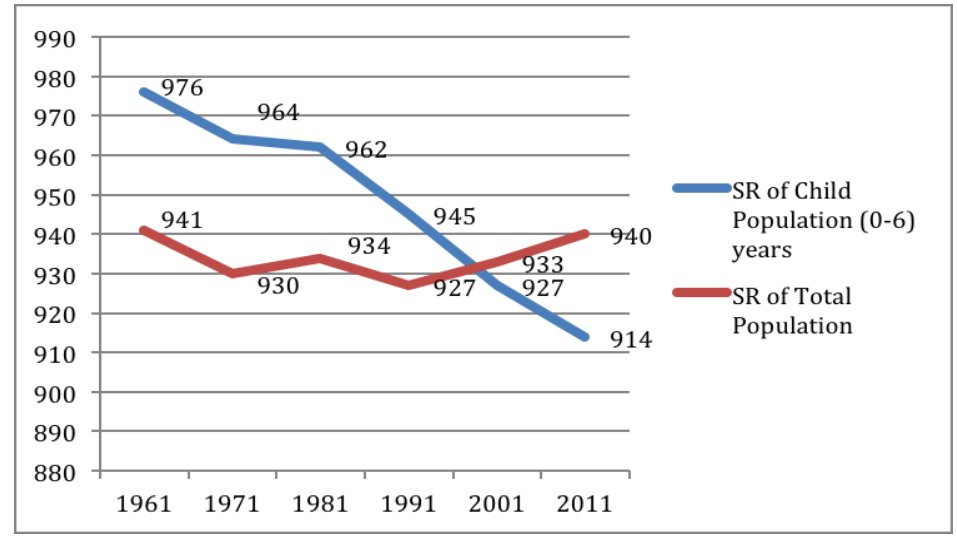

Source: Census of India (2011) cited in Eklund and Purewal (2017) 
This is the accepted version of a forthcoming article that will be published in Feminist Review by Palgrave Macmillan: http://www.palgrave.com/gb/journal/41305

Accepted version downloaded from SOAS Research Online: http://eprints.soas.ac.uk/25115/

The inability of the criminalisation of SSA to increase or improve the sex ratio can be best understood by the resilience of broader structures producing son preferring, sex selection (Eklund and Purewal 2017). The bio-politics of SSA in India has been shaped by several factors: the ascent of neoliberalism at the level of economic, social and political organisation which presents human reproduction as a key element of control and productivity; the reliance of the household and family on traditional patriarchal notions of 'security' through patrimony making sons an essential financial income-earning asset in the absence of state welfare; and state policies which seek to frame a discourse on the sex ratio which avoids addressing these structural dimensions. The claims to 'tradition' which are implicit in the categorical depiction of 'women as mortgaged to a frozen tradition' (Sangari 2015: 37) reify the rationale for SSA rather than situate it within broader structural processes. This leads to women's internalisation which cannot be reduced to the 'tradition' versus 'modernity' characterization of son preference and SSA (Purewal 2010). Instead, state policies have focused on awareness-raising and incentivisation through an anti-discrimination discourse (a 'modernising' tool of the state) which fails to challenge neoliberalism as an economic and political project in India. In July 2015, just before Raksha Bandhan, the Modi government announced a fixed deposit scheme to deepen financial inclusion by announcing that brothers could open fixed deposits in their sisters' names for Rs. 5000 which the government would top up with life and accident insurance. Thus, the 'bond of protection' associated with the ritualistic tying of raakhi or rakhrhi by a sister on a brother's wrist, was, through collaboration with the banking and financial sector, brought into the discourse and cultural code of 'security' of women and girls as sisters through patrimony. Alongside this pet programme was the rolling out of a mass private social security scheme including accidental, life, and pensions cover. This was in contrast to the notion of welfare social security as demonstrated under the quasiwelfare approach of the Congress over the previous decades, including government schemes. Indeed, the Pradhan Mantri Jan Dhan Yojana scheme was merely an extension of the previous Congress government's scheme of financial inclusion in which hitherto only literate people were able to avail a bank account.

Women's exclusion and marginalisation within patriarchal/patrimonial systems of ownership has been well documented (Agarwal 1994). Despite the Hindu Succession 
This is the accepted version of a forthcoming article that will be published in Feminist Review by Palgrave Macmillan: http://www.palgrave.com/gb/journal/41305

Accepted version downloaded from SOAS Research Online: http://eprints.soas.ac.uk/25115/

Amendment Act of 2005 which legally gave women the right to inherit ancestral property, according to a study by Landesa (2013), only one in 10 women whose families own agricultural land actually inherit any land at all,. The study, which was conducted eight years after women were given equal inheritance rights in law, highlighted how dowry continues to be viewed as women's inheritance while men inherit the main assets of the household, enforcing patrimony as the norm. Control over property and control over gender reproduction and sexuality are mutually affirming and highlight the materiality of 'sex' and the effect of power (Butler 1993). Resistance to systematic male/patriarchal proprietary control over women's reproduction and sexuality has been a central concern for radical feminists in articulating the violences that are exerted in order to curb women's autonomy (Wilson and Daly 1992).

Such programmes as the Jan Dhan Yojana scheme have continued to assert the domestic mode of production as the foundation of economic, social and cultural dynamics of the household. The domestic mode of production has been further entrenched and commodified through gender 'norms' of patrimony, gifts, and financial inclusion, rather than addressing women's structural economic, political, social and reproductive/sexual positionalities.

Ultimately, the sex ratio and its associated policy interventions form part of the social requirements of neoliberal patriarchy. It could be argued that the neoliberal state, as it is evolving in India, is contributing to the pressures on the household, which explains for the steadily declining ratios against females. This has occurred under the jurisdiction of the two laws of 1994 (PNDT) and then amended in 2003 (PCPNDT) which, rather than improving the sex ratio, have become part of the apparatus, or structure, of the biopolitics of the state of SSA. While there has been much speculation about how the sex ratio continues to either hover at the level of total population and why it is acute at particular local and 0-6 age group levels, for our purposes here, the failure of state interventions to date highlights how neoliberal governmentality has never been concerned with altering the structural dimensions of sex selection, from its imperialist onset in the Nineteenth century to its present incarnation in Modi's neoliberal state patriarchy. The Indian state has not only been disinterested in asserting public policy which addresses structural dimensions of the sex ratio but it actively promotes and embodies them. 
This is the accepted version of a forthcoming article that will be published in Feminist Review by Palgrave Macmillan: http://www.palgrave.com/gb/journal/41305

Accepted version downloaded from SOAS Research Online: http://eprints.soas.ac.uk/25115/

The outcome of this has been the emergence of an 'anti-female feticide' discourse in India accompanied by an administrative strategy of quotas, targets, and surveillance of records. The threat of being 'named and shamed' for committing SSA as a tool of governmentality looms larger than actually being convicted of breaching the law, as virtually no cases are ever brought forward formally. The performativity of the law, on the one hand, and the state's overarching symbolic role in reflecting patriarchal authority and male dominance as a trope of hegemonic power continue to shape how SSA has been approached through public policy in India. Even the short-lived proposal by Maneka Gandhi (Minister for Women and Child Development) under the BJP government in February 2016 calling to make sex determination tests compulsory for all pregnancies reflected the inversions and embeddedness of gender in structures of the (Hindu majoritarian) state. The argument, which was quickly retracted as comment rather than a proposal, brought to the fore the conundrum for a government Minister to at once have to comment on the criminalisation of SSA (introduced under the Congress governments in $1994 \& 2003$ ) while also representing the neoliberal patriarchal (Hindutva) state in its defense and 'protection' of women and children:

till when will we keep arresting people? In this country, if a person goes to an ultrasound owner and asks for the gender of his (unborn) kid, who will dare say no? (Mascarenhas: 2016).

Brown (1992: 28-29) succinctly outlines the levels of the state's embeddedness within structures of dominance and hegemony, quoted extensively here because of the relevance to the constitution of state structural hegemony:

...the state bears all the familiar elements of male dominance. Through its police and military, the state monopolizes the institutionalised physical power of society. Through its welfare function, the state wields economic power over indigent women, arbitrarily sets the terms of their economic survival, and keeps them 'dangling' and submissive by providing neither dependable, adequate income levels nor quality public daycare. Through age-of-consent laws on contraception, regulation of abortion and other reproductive technologies, and heterosexual stipulations on motherhood, the state controls and regulates the sexual and reproductive construction and condition of women. Through its monopoly of political authority and discourse, the state mediates the discursive, semiotic, and spatial terms of women's political practices. 
This is the accepted version of a forthcoming article that will be published in Feminist Review by Palgrave Macmillan: http://www.palgrave.com/gb/journal/41305

Accepted version downloaded from SOAS Research Online: http://eprints.soas.ac.uk/25115/

The reproductive construction and condition of women is highlighted within Brown's outline of the masculinity of state power. To be more specific to contemporary India's neoliberal patriarchal governmentality, the reproductive domain of power illustrates how India's deepening capitalist class relations and the penetration of neoliberal values to the household and inter-personal relations are being actively promoted by the state. Societal and market responses to the state's activities have seen an increasing and commodification of the value of sons over daughters, with the rise of 'private authorities' in terms of reproductive health, service provision and 'development' projects (Plehwe, et al 2006). The state of sex selective abortion in India therefore constitutes a circular management of, rather than challenge to, son preference and sex selection through the coordinated relationship between social structures, cultural practices and attitudes, economic processes, and systems of governance and governmentality. Sangari (2015: 48) captures this dynamic by stating that 'the state co-constructs patriarchal ideologies and can repress individuation, but, as a terrain of struggle, must also promise emancipation.' Within the neoliberal patriarchal governmentality of contemporary India, as has been highlighted, emancipation has been expressed through the promises of neoliberalism, patriarchy, and Hindutva, as converging ideologies of dominance and hegemony. The outcomes, however, have been far from emancipatory and instead have produced and reproduced structures of violence which, while seeking to highlight SSA as an 'antiwoman' act, also situate it within broader patriarchal and other reifyingly hegemonic relations of the normative family, community and the state which are invested in the very structures of women's dispossession they seek to highlight as being discriminatory. Indeed, the vast body of studies on SSA published over the past few decades have categorically utilised the sex ratio as an indicator in positioning the state as a reformer or harbinger of laws in order to uplift women against trends of female deficit, discrimination, and demographic decline rather than situating the state within the structures of violence which produce daughter de-selection. It is for this reason that the anti-discrimination logic of SSA campaigns and policies have failed to have an influence on the sex ratio and why the state is not removed from the patterns it seeks to address.

\section{Conclusion}


This is the accepted version of a forthcoming article that will be published in Feminist Review by Palgrave Macmillan: http://www.palgrave.com/gb/journal/41305

Accepted version downloaded from SOAS Research Online: http://eprints.soas.ac.uk/25115/

An overarching view of SSA in India illuminates the fact that the advent of and access to reproductive technologies has resulted in tighter connections across structures of violence and dispossession, making the relationship between gender violence and technology one of co-construction rather than a simplified convergence (Grint and Woolgar 1995). State laws to make sex selection illegal operate on an abstracted notion of universal justice through legal jurisdiction. This performative function of law in the context of broader son preferring structures has resulted in a perpetuating enactment of abstracted 'rights' alongside their denial. While the family, which is both a site of women's resistance and patriarchal repression, is embedded within broader state and legal frameworks shaped by and reinforcing patriarchal ideology in its regulation of the normative family (Kapur and Crossman 1996), neoliberal processes have colluded with the state in the creation of neoliberal state patriarchy in India. The neoliberal state in India has utilised existing forms of dominance and control in order to exercise its powers to facilitate the penetration of capitalism at all levels of society. Women's bodies, as sites of the production and reproduction of patriarchy and neoliberalism, are both conditioned to reflect and carry out these ideologies while also being 'protected' or disciplined by the state. The failures of the PCPNDT Act to impact positively on the sex ratio can be best understood through the broader structures of dominance and violence, including reproductive violence, which form the apparatus of India's neoliberal state patriarchy.

Despite the banning and criminalization of sex selection by the state, son preference, which produces the rationale behind daughter de-selection, remains beyond the remit of law and even forms the basis of many 'protection' campaigns such as 'save the girl child' or Beti Bachao, Beti Parhao andolan. As Brown (1992) asserts, institutionalised power of the (male/patriarchal) state asserts institutionalised power through a number of overlapping structures. The concept of neoliberal patriarchy (and governmentality), I argue, deepens our analysis to include the embeddedness of neoliberal and patriarchal ideologies at all levels of the structure. Thus, structural power is exercised across the institutionalised physical power which is wielded through the military and policing (including moral policing); through economic power through the insistence on men's proprietary ownership and women's 'dangling' financial dependence; through reproductive power and 'traditional' notions of motherhood, (hetero)sexuality and regulation; and finally, through political power through the monopolisation and 
This is the accepted version of a forthcoming article that will be published in Feminist Review by Palgrave Macmillan: http://www.palgrave.com/gb/journal/41305

Accepted version downloaded from SOAS Research Online: http://eprints.soas.ac.uk/25115/

mediation of women's political mobilities and practices. Neoliberal state patriarchy has become an extant form of governmentality in contemporary India, most notably since the 2014 formation of Narendra Modi's BJP government, as it has fortified its structures of power.

The display of 'protection' and 'safety' as a state response to gender violence reveals the nature of the state's discursive articulation of its own authority and power vis-à-vis patriarchal ideology and institutions ranging from the highest levels of state authority to the family. As Sangari argues, this highlights how 'the stated fears of violence against prospective daughters can lead to amassing the perceived means of violence - sons - and aggravate the same social deformations that are said to make daughters undesirable' (2015: 37). Furthermore, within the force field of Hindutva the hyping of insecurity forms the backdrop to caste-based and communal violence. The 'protection' of women from rape, sexual abuse, and autonomous choices around love, romance, and marriage constructs sons as defenders and protectors and women as vulnerable, defenseless, and in need of 'protection', symbolized in the ritual of Raksha Bandhan and 'save the daughter' campaigns and discourse. However, the individualism implicit in neoliberal processes has also led to greater demands for 'rights' in calling for gender justice, albeit within a liberal framework which has been hitherto problematised for ignoring structural dimensions of gendered violence. This contradiction is what lies at the centre of neoliberal patriarchy and which perpetuates the tensions around individual 'rights' which are simultaneously upheld and undermined through state-endorsed neoliberalism.

There is also a class and caste dimension to the 'save the girl child' and financial inclusion campaigns which carry a rhetoric to 'civilise' daughter discrimination through access to banking and incentives to 'protect' girls. While sex selective abortion has not been known to be practiced amongst Dalits, patriarchy and 'honour' have been found to be on the rise amongst dalits where economic and political upward mobility has occurred (Still 2017). This may result in SSA spreading through this performance of 'honour' where it previously was not evident.

A feminist critique of the neoliberal patriarchal governmentality of SSA in India requires a recognition that concepts such as the 'woman question' or the 'girl child' as victims are 
This is the accepted version of a forthcoming article that will be published in Feminist Review by Palgrave Macmillan: http://www.palgrave.com/gb/journal/41305

Accepted version downloaded from SOAS Research Online: http://eprints.soas.ac.uk/25115/

not only insufficient to address structurally produced violence but also that the economic, political and social ideologies which are producing violence can no longer be left unchallenged in the exploitation of violence for power and control. As I have argued, the discourse on SSA in India has emerged from within the deepening of a neoliberal capitalist regime of development and a Hindutva ideological political landscape. To develop a feminist analysis of SSA and the protectionism which frames both policy and discourse is to draw linkages and to underscore convergences which constitute counterinsurgency campaigns, such as the mutually reinforcing ideologies of Hindutva and neoliberalism which are omnipresent in Modi's BJP governmentality. It is here that the structurally situated position of SSA comes to the fore as both a matter for household rule (oikonomia) and its dominance by counterinsurgency practices within what Owens' (2015) calls the 'rise of the social' and 'armed social work'. As this article has highlighted, the failures of state policies in India to address SSA have to do not with society's resistance to governmentality but with the embedded nature of SSA structurally. The neoliberal state's position is, as has been argued, duplicitously aligned with structural violence while discursively opposing SSA. 'Protection,' as exemplified in the statements by BJP political leaders surrounding the 'Love Jihad' and 'anti-Romeo' statements and the Beti Bachao, Beti Parhao programme, is implicitly and explicitly a patriarchal coconstruction across economic, political, reproductive, and physical power and violences which are exerted on women and which the state ironically purports to 'protect' them from.

\section{References}

Agarwal, B. (1994) A Field of One's Own, Cambridge: Cambridge University Press.

Anandhi, S., K. Kapadia, eds Dalit Women: Vanguard of an Alternate Politics in India

Banaji, J. (2010) Theory as History: Essays on Modes of Production and Exploitation, Brill.

Brown, W. (1992) 'Finding the man in the state,' Feminist Studies, Vol. 18, No. 1, pp. Spring 1992, pp. 7-34. 
This is the accepted version of a forthcoming article that will be published in Feminist Review by Palgrave Macmillan: http://www.palgrave.com/gb/journal/41305

Accepted version downloaded from SOAS Research Online: http://eprints.soas.ac.uk/25115/

Brown, W. (2015) Undoing the Demos: Neoliberalism's Stealth Revolution, MIT Press.

Butler, J. (1993) Bodies That Matter: On the Discursive Limits of 'Sex,' Routledge: New York.

Campbell, B. (2015) 'After neoliberalism: the need for a gender revolution' in Stuart Hall, Doreen Massey and Michael Rustin (eds.), After Neoliberalism? The Kilburn Manifesto. http://www.lwbooks.co.uk/journals/soundings/pdfs/manifesto_gender_revolution.pdf

Chinai, R. (2004) 'Even If We Shout There is No One to Hear: Reproductive Health Issues among the Marginalized Population of Nagaland' in M. Rao (ed.) The Unheard Scream: Reproductive Health and Women's Lives in India, Zubaan: New Delhi, pp. 109126.

Chowdhry, P. (2011) 'Men, Marriage and Sexuality in Northern India' in S. Sen, R. Biswas and N. Dhawan (eds.) Intimate Others: Marriage and Sexualities in India. Stree: Kolkata.

Das, V. (2000) 'The Act of Witnessing: Violence, Poisonous Knowledge and Subjectivity' in V. Das, A. Kleinman, M. Ramphele, and P. Reynolds (eds.) Violence and Subjectivity, pp. 205-225.

Economic Times (2015) http://blogs.economictimes.indiatimes.com/wpcontent/uploads/2015/08/Modi-Raksha.jpg

Eklund, L. and Purewal, N. (2017) The Bio-politics of Population Control and Sex Selective Abortion in China and India,' Feminism and Psychology., pp. 34-55.

Galtung, J. (1969) 'Violence, Peace and Peace Research,' Journal of Peace Research, Vol. 6, No. 3, pp. 167-187.

Gupta, A. and Sharma, A. (2006) 'Globalization and Postcolonial States, Current Anthropology, Vol. 7, No. 2, April 2006, pp. 277-307. 
This is the accepted version of a forthcoming article that will be published in Feminist Review by Palgrave Macmillan: http://www.palgrave.com/gb/journal/41305

Accepted version downloaded from SOAS Research Online: http://eprints.soas.ac.uk/25115/

Grint, K. and S. Woolgar (1995) 'On some failures of nerve in constructivist and feminist analyses of technology,' Science, Technology \& Human Values, 20(3): 286-310.

Harvey, D. (2005) A Brief History of Neoliberalism, Oxford University Press: Oxford.

Jandial, S. (2017) 'After U.P.'s Anti-Romeo Squads, Madhya Pradesh to Launch AntiMajnoo Squads,' India Today, http://indiatoday.intoday.in/story/anti-romeo-squadsmadhya-pradesh-shivraj-singh-chouhan/1/917951.html

John, M. R. Kaur, R. Palriwala and S. Raju (2009) Dispensing with Daughters: Technology, Society, Economy in North India, Economic and Political Weekly, Vol. XLIV, No. 15, pp. 16-19.

Kapur, R. and B. Crossman (1996) Subversive Sites: Feminist Engagements with Law in India. New Delhi: Sage Publications: New Delhi.

Kasun, J.R. (1999) The War Against Population: The Economics and Ideology of Population Control, San Francisco: Ignatious Press.

Kaur, R. (2015) ‘Tackling India’s Bare Branches’, Seminar, 665, pp. 63-67.

Kelkar, G. (1992) "Women and Structural Violence in India" in J. Radford and D.E.H. Russell (eds.) Femicide: The Politics of Woman Killing, New York: Twayne Publishers.

Krishnan, S. (2017) 'They Need Protection, Not Independence: How CM Yogi Views Women, The Quint, https://www.thequint.com/politics/2017/03/21/yogi-adityanathviews-on-women-uttar-pradesh-chief-minister, accessed 21 March 2017.

Landesa: Rural Development Institute (2013) Report on The Formal and Informal Barriers in the Implementation of the Hindu Succession (Amendment) Act 2005, http://www.landesa.org/wp-content/uploads/hsaa-study-report.pdf. (Accessed 2 March 2017).

Major, A. (2005) 'Ritualism and Symbolism in the Anti-Infanticide Campaign in Early Colonial Punjab,' Journal of Punjab Studies, 12 (1), 96-110. 
This is the accepted version of a forthcoming article that will be published in Feminist Review by Palgrave Macmillan: http://www.palgrave.com/gb/journal/41305

Accepted version downloaded from SOAS Research Online: http://eprints.soas.ac.uk/25115/

Mascarenhas, A. (2016) 'Sex determination: An old law, a new debate,' Indian Express, February 4, 2016, Accessed $26 \quad$ February 2017, http://indianexpress.com/article/explained/sex-determination-an-old-law-a-new-debate/

Menon, N. (1995) The impossibility of 'justice': female foeticide and feminist discourse on abortion, Contributions to Indian Sociology, January-December, (1-2), 369-392.

Oldenburg, V.T. (2002) Dowry Murder: The Imperial Origins of a Cultural Crime, New York: Oxford University Press.

Owens, Patricia (2015) Economy of Force: Counterinsurgency and the Historical Rise of the Social, Cambridge: Cambridge University Press.

Panigrahi, L. (1972) British Social Policy and Female Infanticide in India, Delhi: Munshiram Manoharlal.

Patel, T. (2007) Sex-Selective Abortion in India: Gender, Society and New Reproductive Technologies, Sage: New Delhi.

Patel, V. (1989) 'Sex Determination and Sex Pre-selection Tests in India: Modern Techniques for Femicide,' Bulletin for Concerned Asian Scholars, 21(1), January-March.

Plehwe, D., B .Walpen, and G. Neunhoffer (2006) Neoliberal Hegemony: A Global Critique, Routledge: London and New York.

Purewal, N. (2010) Son Preference: Sex Selection, Gender and Culture in South Asia, Berg: Oxford.

Purewal, N. and Eklund, L. (2017) "'Gendercide" and the Criminalisation of Sex Selective Abortion in Neoliberal Europe', Global Public Health.

DOI: $10.1080 / 17441692.2017 .1289230$

Rao, Mohan (2004) 'Cairo and After: Flip Flops on Population Policy in M. Rao (ed.) The Unheard Scream: Reproductive Health and Women's Lives in India, Zubaan: New Delhi, pp. 1-20. 
This is the accepted version of a forthcoming article that will be published in Feminist Review by Palgrave Macmillan: http://www.palgrave.com/gb/journal/41305

Accepted version downloaded from SOAS Research Online: http://eprints.soas.ac.uk/25115/

Ravindra, R. (1987) 'Struggle Against Sex Determination Techniques: Unfinished Battle,' Economic and Political Weekly, 19(15), 14 April: 648-52.

Rowland, R (1992) Living Laboratories: Women and Reproductive Technologies, Bloomington, IN: Indiana University Press.

Sangari, K. (2015) Solid: Liquid: A Transnational Reproductive Formation, Tulika Books: New Delhi.

Sarkar, T. (2001) Hindu Wife, Hindu Nation: Community, Religion and Cultural Nationalism, Indiana University Press: Bloomington.

Sen, S. (2002) 'The Savage Family: Colonialism and Female Infanticide in Nineteenth Century India,' Journal of Women's History, 14(3): 53-79.

Sharma, A. (2010) Paradoxes of Empowerment: Development, Gender and Governance in Neoliberal India, Zubaan: New Delhi.

Srivasan, S. (2004) 'Selling the Parenthood Dream' in Mohan Rao (ed.) The Unheard Scream: Reproductive Health and Women's Lives in India, Zubaan: New Delhi, pp. 4566.

Still, C. (2017) Dalit Women: Honour and Patriarchy in South India, Routledge: London.

Strathern, M. (1992) Reproducing the Future: Essays on Anthropology, Kinship and the New Reproductive Technologies, Manchester University Press: Manchester.

Vishwanath, L.S. (2000) Female Infanticide and Social Structure: A Socio-Historical Study in Western and Northern India, New Delhi: Hindustan Publishing.

Wacquant, L. (2009) Punishing the Poor: The Neoliberal Government of Social Insecurity, Duke University Press: Durham and London. 
This is the accepted version of a forthcoming article that will be published in Feminist Review by Palgrave Macmillan: http://www.palgrave.com/gb/journal/41305

Accepted version downloaded from SOAS Research Online: http://eprints.soas.ac.uk/25115/

Wilson, K., 2012 'Race', racism and development: Interrogating history, discourse and practice, London: Zed Books. 